\title{
Analysis of Learning Material on 4-Stroke Engine Tune-Up Practice of Motorcycle Engineering
}

\author{
Suryo Hartanto1, Handoko², and Zaenal Arifin ${ }^{3}$ \\ ${ }^{1}$ Mechanical Engineering Riau Kepulauan University, Indonesia \\ ${ }^{2}$ Technician Department of Mitra Krida Perkasa AHASS, Indonesia \\ ${ }^{3}$ Industrial Engineering, Riau Kepulauan University, Indonesia
}

\section{Abstract}

The gap appears between the demands of industrial work skills and the school circumstances in terms of student learning materials in vocational high school of motorcycles engineering department. This study at revealing the learning materials scope of 4-stroke engine tune up among the students of motorcycle engineering department in vocational high school. This study can be categorized as descriptive

Corresponding Author:

Suryo Hartanto

suryo@fkip.unrika.ac.id

Received: 18 January 2019

Accepted: 24 March 2019

Published: 31 March 2019

Publishing services provided by

Knowledge E

(c) Suryo Hartanto et al. This article is distributed under the terms of the Creative Commons Attribution License, which permits unrestricted use and redistribution provided that the original author and source are credited.

Selection and Peer-review under the responsibility of the ICEST 2018 Conference Committee. quantitative. The research respondents consisted of 30 people, they were mechanic, head of mechanic, and Service Advisor (SA) from authorized workshop of Honda or AHASS and the vocational high school teachers of motorcycles engineering. The research instruments used the questionnaires that had been examined for its validity and reliability. Based on the research result, industry party need the learning material of 4-stroke motorcycle tune-up. It requires 100 topics/ sub topics of materials but there are only 35 topics/ sub topics covered in SMK syllabus. It means 65 topic/ sub topic as the gap. Moreover, the subject of 4-stroke motorcycle tune-up in motorcycle engineering department of vocational high school need to be adjusted to meet the standard requirements of the world of work for motorcycle engineering field as much as 65 topics/ sub topics

Keywords: Learning materials, 4-stroke engine, tune- up, Vocational education

\section{Introduction}

The automotive world has developed rapidly in recent years and it requires creativity and innovation to seize the competition. Every year motorcycle manufacturers launch their new products by adopting the current sophisticated technology in order to compete 
manufacturer has several patented technology, such as Programed Fuel Injection (PGMFI), Enhanced Smart Power (ESP) technology, swit stand, combi break system, Idling Stop System (ISS), Alternating Current Generator (ACG) starter.[3]

To respond the challenges of this technological advancement, vocational high school (Sekolah Menengah Kejuruan or SMK) plays an important role. Since SMK as a work oriented education program with one of its missions is to improve the quality of graduates in accordance with National Competency Standards.[7]. Vocational education is trying to prepare competent individuals to be able to develop careers in the future. However, it has not been completely achieved. The Central Bureau of Statistics in 2015 noted that the number of unemployment in Indonesia in August 2015 has increased into 110 thousand people becoming 7.56 million people from 7.45 million people in February 2015. Surprisingly, it is dominated by SMK graduates and the unemployment rate for vocational education occupies the highest position with $12.6 \%$.

This condition is triggered by the lack of student competence in the working process, which is known during their internship or industrial work practices. Most of motorcycle companies that receive and train apprentices find that many students are inadequate to master knowledge and skills, especially in tune-up, electricity, and devices measurement. The students also often make mistakes in performing their work, such as periodic maintenance procedures of tune-up (checking and repairing), analyzing the problems on engine malfunction, determining the usage duration and the wear parts that must be replaced. The lack of competence has an impact with the indication of the increase in unemployment rate from SMK graduates. The problems mentioned above become one of the important signal for immediate improvement and change.

Education is a manifestation of dynamic human art and culture as well as the development requirement, therefore the change or the development of education should be followed and influenced by changes in all aspects of society (economy, science and technology, socio-cultural),[9]. the knowledge that is obtained in the form of facts, concepts, procedures and principles of the students can be so by involving interaction with external environment that can change someone's behavior.[12]. Changes, in the meaning of improving the educational process at all levels, need to be continuously done to anticipate of future interests.

To reduce the gap between the demands of industry-defined capability and the material learned in SMK, it requires the relevance from both parties to bridge the difference. An effort that can be made, such as by having industry assessment on the material that need to be given to vocational students as prospective workers. In addition, it is necessary to evaluate the material on SMK curriculum to answer the needs of the world 
of work. This relevance and the evaluation process can assist SMK in preparing ready-touse graduates. The materials should be tailored to the community needs, the workplace needs, as well as it should be fun and interactive to build student skill competencies effectively. The learning materials in SMK presented in various competencies are important for the students' future. Those competencies are required to become intelligent Indonesian and competent workers based on the competency standards established by industry, business world and professional associations. To achieve the standard of competence, the material content should be packed in groups of subjects and organized into normative, adaptive and productive program.

Motorcycle engineering department in SMK is designed to teach and to improve the competence of motorcycle engineering expertise. The Law of National Education System Article 3 and 15 states that vocational education is a secondary education that prepares students to work in a particular field. Specifically, the competence objective of motorcycle engineering expertise is to equip students with the skills, knowledge and attitude to be competent in the areas of maintenance and repair of motorcycle on a) engine, b) power transfer system, c) chassis and suspension, d) electrical systems.

The competence of motorcycle engineering in this research is related to competence for 4-stroke engine motorcycle. It includes in the category of motor fuel. The combustion engine is a kind of heat engine that converts the chemical from fuel into mechanical power and the conversion is carried out in the machine inside.[4]. In general, combustion engines in the ICE (Internal Combustion Engine) consists of two types of motor 4 and 2-stroke engine, each type has its own advantages and disadvantages. 4-stroke engine performs four steps process of suction, compression, power, and exhaust, twice crankshaft, one-time camshaft rotation and one burning or power.

The machine in motorcycle needs to be taken care to keep the engine in top performance. Tune-ups and schedules service that marginal and out-of-tolerance adjustments are routinely corrected.[1] Tune-up is part of regular maintenance activities on motorcycles, which include: a) examining the parts of the motorcycle to make sure it functions properly, b) cleaning the dirty parts to prevent the system damage c) setting the changed parts to match the specifications. d). repairing or replacing the wear parts. Tune-up consists of inspecting, testing, and adjusting the motorcycle. [1]. The part that get tune-up cover 1) fuel channel, 2) fuel filter, 3) hand gas system, 4. carburetor, 5) air filter, 6) spark plug, 7) swing valve, 8) engine oil, 9) oil filter, 10) stationary machine rotation, 11) chain wheel, 12) battery liquid (battery water), 13) oil brake discs, 14). wear of brake shoe, 15) brake system, 16) rear brake light switch, 17) headlights direction, 18). 
coupling System, 19) side-stand, 20) front \& rear suspension, 21) bolt \& fastener, 22) wheels or tires, 23) steering wheel head. [3].

TABLE 1: The Parts Of Motorcycle Tune-Up.

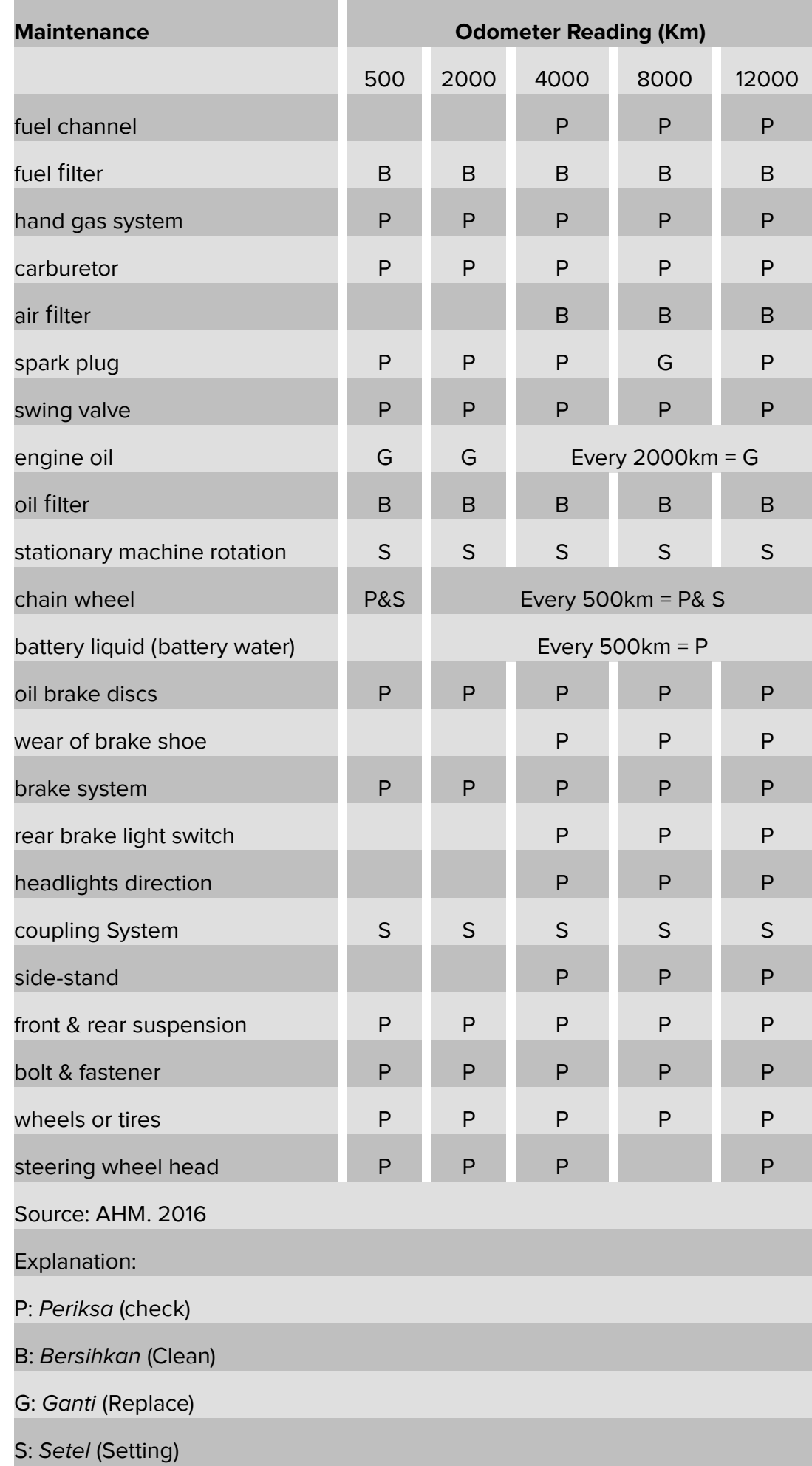


The urgency of competent labor of motorcycle engineering expertise from vocational high school is affected by the advancement of technological transformation. It makes the learning materials analysis should be done to support the knowledge and ability of vocational high school students in order to compete future work world. This analysis is also expected to be a reference for teachers and relevant to improve the competence of vocational high school students, especially for the motorcycle engineering field. The purpose of this study is to explain the scope of the practice material of 4-stroke engine motorcycle tune-up for motorcycle engineering department of SMK in order to fulfil the needs of the industry and the world of work.

\section{Research Methodology}

This research can be categorized as descriptive quantitative which is explorative without hypothesis. The research analysis used DACUM approach where Developing Curriculum is the most effective analytical technique. It is usually used by industry practitioners, educators and consultants to identify tasks, jobs and information related to jobs and jobs.[10], [7]. The research sample consisted of mechanic, head of workshop, service advisor at authorized Honda workshop (AHASS) amounted to 24 respondents from 6 workshops, 6 vocational teachers of motorcycle engineering from 2 vocational high school, so that the total sample was 30 respondents. The questionnaires was to measure the strength and weakness of the material scope of 4-stroke engine motorcycle tuneup using the respondents' opinion about the importance of material presented in the questionnaire.

The content validity test was performed by 5 experts. The points that must be considered by the expert in reviewing the contents of the instrument including 1 ) the instrument should be based on the indicator, 2) the item is written short and clear, 3) the choice is in the form of good order numbers, 4) the similar component of each item is given the same score (the same score does not mean the answer option is similar), and 5) the item is written with the standard language.[8]. After having the expert validation analysis, this descriptive instrument met a very good criterion and can be used without revision meanwhile, for its reliability, the score was 0.679 with significance at 0.019 , It mean then the overall instrument was declared valid and reliable

The analysis of learning material requirement of 4-stroke engine motorcycle tune-up was not expressed in terms of respondent's level of achievement of the percentage. The decision criterion were using the selected learning materials of 4-stroke engine motorcycle tune-up practice and it had the respondent's level of achievement which was 
more than 50\% from the category of "very important" and "important",[7]. The results of the respondents' level of achievement was, then, compared with the current motorcycle learning materials in the vocational high school. The research decision making was the learning material found in the requirements analysis with the percentage of more than $50 \%$, and, as the research finding, it can be used as reference for the curriculum structure changes or the additional material on motorcycle engineering for tune-up practice.

\section{Result and Discussion}

The needs analysis is done to get a real picture on the job field of the expected competence in accordance with the employment needs,[7]. There are some skills that are demanded in the industry and manufacturing, the skills need will be very important as the defense of the information development and the environment rapidly. It shows that the specificity is very crucial in the industry or working world and it should be used by education institutions to be able to adapt to the current technology and today's people needs.

The respondents' responses on the learning materials for the 4-stroke motorcycles tune up categorized as "very important", "important", "less important", and "unimportant" to each item of the material. Furthermore, their 'answers were divided into "very important" and "important" category with "less important" and "unimportant" categories. It was to separate the learning materials considered important by the respondents which should be learned by the vocational students and the unnecessary one. The data showed that "important and "very important" category reached above 50\% and 100 subjects/ sub topic material fell into the category of "very important" and "important". This category of "very important" and "important" then compared with the materials of 4-stroke motorcycles tune up in the current SMK curriculum. The recommended learning materials had not been listed in the SMK curriculum and those were considered very important to be taught to the vocational high school students of motorcycle engineering program.

Based on the comparison data on the material coverage, it was found that some material did not include yet in the syllabus of 4-stroke motorcycle tune-up subjects of vocational high school. The recent syllabus only covered 35 topics/ sub topics of material while, based on the research result, it should be 100 topics/ sub topics. It means the recommended material that should be added as much as 65 topics/ sub topic. Below are the topics/ sub topics based on the research findings. 


\subsection{5 the topics/ sub topics of tune-up materials based on the syllabus}

\subsubsection{Motorcycle fuel system}

1) knowing the components and the functions of the fuel system, 2) understanding and knowing the components and functions of the carburetor. 3) understanding and knowing the components of the fuel injection system, 4) Diagnostic error on the fuel system, 2. Repairing the engine and its components: 5) Understanding the engine maintenance, 3. Execute cylinder head overhaul and cylinder block: 6) disassembling the cylinder head components and the cylinder block. 7) measuring the cylinder head and the cylinder block based on the manufacturer's specifications, 4. Conducting periodic maintenance on the lubrication system: 8 ) understanding the function and the operation of the lubrication component. 9) diagnosis the lubricant system malfunction, $\mathbf{5}$. Conducting the cooling system treatment: 10). Diagnostic error on the cooling system, 6. Repairing the clutch unit on operating system components (manual \& automatic): 11) identifying the clutch and the components operation system. 12) diagnostic error on the coupling system and its components operating system, 7. Conducting manual transmission repair: 13) identifying the components of manual transmission. 14) diagnostic error on the manual transmission system, 8. Conducting automatic transmission repair: 15) identifying the automatic transmission components. 16). Diagnostic error on automatic transmission systems. 17) Fixing the error one automatic transmission system, 9. Gear mechanism: 18) understanding the gear function and the operation system 19) identifying gear mechanism components. 20). Diagnosis the damage on gear mechanism, 10. Conducting repair of mechanical starter system: 21) understanding the function and the operation of mechanical starter, 22) mechanical starter repair, 11. Repairing the suspension system / Shock absorbers: 23 ) identifying the component of shock absorber mechanism. 24). Diagnostic error in the suspension system (corrosion, oil leakage, air leakage, wear, and alignment). 25) repairing suspension system, 12. Check and repair the wheels, tires, and chains: 26) overhaul the wheels, tires, and chain/ gear sets, 13. Repairing the charging system: 27$)$ identifying the components charging system. 28) Error diagnostic in the charging system. 29) repairing the error on the charging system, 14. Repairing the lighting system: 30$)$ identifying the light and load components system, 15. Conducting the starter system: 31) Identifying the starter system component. 32). error diagnostic on the starter system. 33). Repair the error on the starter system, 16. System PGM-FI/ injection: 34). understanding the function of PGM-FI system components. 35). Error diagnostic in PGM-FI system. 


\subsection{5 topics/ sub topics of the material based on the research findings}

\subsubsection{The operation principle of 4-stroke engine motorcycle}

1) understanding the term of TMA \& TMB in the machine, 2) understanding the operation principle of 4-stroke engine motorcycle, 3) knowing the difference of 4-stroke and 2stroke system, 4) knowing the strength and the weakness of 4-stroke engine. B. Motorcycle fuel system: 5) understanding the fuel system, 6). knowing various type of motorcycle carburetor, 7). repairing the error on the fuel system, $\mathbf{C}$. Repairing the engine and its components: 8) identifying the engine types, 9) understanding the engine specifications, 10 ) identifying the engine components, 11). known the functions and the operation of the engine parts, 12) taking off and assembling the engine components 13) error diagnostic on the engine, 14) understanding the engine adjustment (valve set, spark plug gap, and Sim replacement). D. Conducting a cylinder head and cylinder block overhaul: 15). testing the cracks with the chemical liquids, 16). Fixing the component of cylinder head and cylinder block, E. Repairing the ignition system: 17) identifying the component of ignition system, 18) error diagnostic on the ignition system, 19) repairing ignition system, F. Conducting periodic maintenance of lubrication system: 20) understanding the types of lubrication system, 21) knowing the types of lubricating oil and its viscosity, 22) knowing the ideal distance for oil replacement based on the level of oil/ oil lubricant viscosity. G. Conducting cooling system maintenance: 23). understanding the working principle of water and air cooling system, 24) understanding the types of coolant and its usefulness, 25) understanding the duration of refrigerant usage, 26) repairing the cooling system disorder, $\mathbf{H}$. Repairing the clutch unit and its operating system components (manual \& automatic): 27 ) fixing the damage of the coupling system and its operating components, I. Conducting manual transmission repair 28) repairing the manual transmission system, J. Gear mechanism: 29) understanding gear mechanism components, K. Repairing mechanical starter system: 30) Error Diagnostic on mechanical starter, L. Frame: 31) identifying the frame part type, 32) understanding the frame section specifications, 33). understanding the difference, 34) knowing the part, 35) knowing the function. M. Repairing suspension system/ shock absorbers: 36 ). knowing the suspensions types, $\mathbf{N}$. Checking and repairing wheels, tires, and chains: 37) identifying the type of tires (outside \& inside part) and its specifications, 38) error diagnostic on wheels, tires, and chain drive systems, 39). repairing/ replacing the tubeless tires, O. Repair brake systems (tromol \& discs): 40) identifying the brake system components, 41) replacing and installing the brake systems, 42) repairing and adjusting 
the brake system, 43) understanding the replacement guides, 44) understanding the electrical parts, 45) understanding the electrical parts specifications, 46) understanding the difference of the electrical parts, 47) understanding the electrical parts function 48) knowing the symbols and codes of the electrical system, 49) understanding the connector functions, 50) knowing the connectors types, 51) understanding the circuit series, parallel, combination, P. Repairing lighting system: 52) understanding the electrical diagrams, 53) understanding and memorizing the blink signs of error, 54) soldering, 55) using test lamps, 56). understanding types of bolamp voltages, 57) knowing the use of multitester, Q. PGM-FI system/ injection: 58). understanding components of PGM-FI system, 59) PGM- FI system warranty conditions, 60). memorizing and understanding mile blinking code, 61) understanding the setting of altitude mode. R. Current Motorcycle Technology System: 62) CBS system (Combination Break System), 63) ACG Starter system, 64) ISS (Idling Stop System) system, 65) ESP system (Exchanged Smart Power).

The need analysis in this research is to know the gap between the expectation and the reality in the school \& the industry. The competence of vocational education can be effective if the students in the learning process are taught through a real experience to create behavior, thinking and good actions in the work,[11]. Based on that view, the vocational education must create learning conditions in accordance with the real work field and provide learning in accordance with the needs of the world of work to make sure the vocational education students meet the labor market. Vocational education as part of education which makes an individual more employable in one group of occupations the other [5], [2]. The education in the future should have the goals and orientations to socialize people into appropriate attitudes for the world of work, as well as to orientate people to understand the world of employment and to prepare for the choices and transition that they will have to make to entering it, prepare them with specific skills and knowledge to apply in a direct way after becoming employment.

The need analysis findings on the materials of 4-stroke engine tune-up of motorcycle engineering on vocational high school need to be followed up by the school policy maker. The facts and reality show that a lot of material is still not covered all in the syllabus material 4-stroke engine motorcycle tune-up. The immediate evaluation should be made in case of the materials in the school curriculum to avoid the decrease on the students' competence. The development of automotive technology is so rapid that demand the education institution to improve the materials and the learning process aligning with the community needs as well as to improve the competence of vocational high school students. 


\section{Conclusion}

Based on the research result, it can be concluded that the scope of practice material of 4-stroke engine motorcycle tune-up on the motorcycle engineering of vocational high school in the current curriculum has 35 topics/ sub topics of material while the "very important" and "important" category of the materials is 100 topics/ sub topics. The results of this study indicate that there is a gap between the learning materials in the school with the industrial needs. Therefore, the existing learning material of 4-stroke engine motorcycle tune-up need to be improved to enhance the competence of the vocational students

\section{Acknowledgement}

We would like to thank those who have supported the successful implementation of this research. All employees and management authorized Honda motorcycle workshop (AHASS) Batam. Lecturers and staff of Riau Kepulauan University. Principals, teachers and staff at SMK Negeri 3 Batam, SMK Hang Nadim Batam and some parties can not be mentioned one by one.

\section{References}

[1] Abdo, E. (2014). Motorcycle Maintenance.

[2] Adrian, F. (2005). The Psychology of Behaviour at Work. the individual in the organization (2nd ed.). New York: Psychology Press.

[3] AHTC. (2016). Materi Honda Teknologi.

[4] Daryanto. (2004). Teknik Sepeda Motor (VI). Bandung: Yrama Widya.

[5] Evans, R. N., \& Herr, E. L. (1978). Foundation of Vocational Education (2nd ed.). Ohio: Charles E. Merril. A Bell \& Howell.

[6] Hartanto, S. (2016). Pengembangan model pembelajaran Soft Skills Siswa Jurusan Teknik Mesin SMK. Universitas Riau Kepulauan.

[7] Hartanto, S., Lubis, S., \& Rizal, F. (2017). Need And Analysis Of Soft Skills For Students Of The Mechanical Engineering Department Of Vocational, 12(30), 156-159. https: //doi.org/http://dx.doi.org/10.21660/2017.30.TVET017

[8] Kartowagiran, B., Tanggal, E. K. S., Yogyakarta, T. K. M., Pascsrjana, D., Teknik, F., \& Negeri, U. (2009). Penyusunan Instrumen Kinerja SMK-SBI Universitas Negeri Yogyakarta, (November). 
[9] Mardiyanto. (2010). Tingkat Kesesuaian Antara Materi Ajar Tune Up Mobil Pada Program Keahlian Teknik Mekanik.

[10] Norton, R. E. (2004). The DACUM Curriculum Development Process, 1-9.

[11] Proser's. C.A. dan Quigley, T.. (1949). Vocational education in a democracy, American Technical society. Chicago. Retrieved from http://www.morgancc.edu/.../prossers

[12] Rukun, K., Huda, A., \& Hartanto, S. (2015). Designing Interactive Tutorial Compact Disc For Computer Network Subject, 23(Cd), 21-26. https://doi.org/http://dx.doi.org/ 10.11113/jt.v77.6682 